\title{
PENGARUH REALISASI PENERIMAAN PAJAK BAGI PERTUMBUHAN PEREKONOMIAN NEGARA INDONESIA
}

\author{
Wahyu Nuning Sumaryani \\ Fungsional Statistisi BPS Kabupaten Karanganyar \\ wenuninges@gmail.com
}

\begin{abstract}
Economic growth is a matter of the economy in the long term and is influenced by various factors. This study aimed to analyze the effects of taxes, inflation, unemployment, and education to economic growth in Indonesia. The analytical method used is the Error Correction Model (ECM). For the purpose of analysis used secondary data such as time series, 1988 - 2017, ie tax revenue, inflation, unemployment and education of Indonesia's GDP. Data were obtained from the Central Statistics Agency (BPS). The estimated using Error Correction Model (ECM) in examining the factors that influence the growth of the economy showed that the short-term and long-term tax revenue have a positive effect, in the long term inflation is positive and significant. Unemployment in the long-term positive and significant impact, while education is also a positive influence and significant impact on economic growth in Indonesia. Indonesia's economic growth will be enhanced by a variety of ways, including the government should to maximize tax revenue as a source of national development costs, control and curb inflation, increase employment and laborintensive orientation, and improve the quality of human resources as economic actors and to improve the quality of education.
\end{abstract}

Keywords: economic growth, tax revenue, inflation, unemployment, education, ECM.

Abstraksi. Pertumbuhandalam Ekonomi adalah masalah perekonomian untuk jangka waktu panjang dan mendapat pengaruh dari banyak faktor. Penelitian ini memiliki tujuan menganalisis pengaruh realisasi penerimaan pajak, pendidikan, inflasi, dan pengangguran, terhadap pertumbuhan perekonomian Indonesia. Metode analisis yang dipergunakan yaitu Error Correction Model (ECM). Digunakan data sekunder (untuk tujuan analisis) yaitu data time series tahun 1988 - 2017, berupa data realisasi penerimaan pajak, pengangguran, inflasi, pendidikan dan PDB Indonesia. Data dimaksud didapat dari sumber data Badan Pusat Statistik (BPS). Hasil estimasi mempergunakan Error Correction Model (ECM) saat meneliti faktor yang memberikan pengaruh pertumbuhan ekonomi memperlihatkan dalam jangka waktu pendek maupun jangka waktu panjang realisasi penerimaan pajak memiliki pengaruh positif kepada pertumbuhan ekonomi. Inflasi berpengaruh positif dan pngaruh signifikan dalam jangka waktu panjang. Pengangguran dalam jangka waktu panjang memiliki pengaruh positif dan signifikan, sedang pendidikan juga memiliki pengaruh positif dan pengaruh signifikan kepada pertumbuhan ekonomi negara Indonesia. Pertumbuhan ekonomi negara Indonesia bisa ditingkatkan lagi dengan bermacam cara, diantara caranya yaitu pemerintah semestinya memaksimalkan perolehan realisasi pajak nasional yang mrupakan sumber pembiayaan pembangunan, mengendalikan dan mengontrol tingkat inflasi, memperbesar lapangan pekerjaan dengan orientasi padat karya, dan meningkatkan mutu SDM sebagai pelaku ekonomi dengan memperbaiki mutu pendidikan.

Kata kunci: pertumbuhan ekonomi, penerimaan pajak, inflasi, pengangguran, pendidikan, ECM. 


\section{PENDAHULUAN}

Penelitian mengenai pengaruh penerimaan pajak bagi pertumbuhan ekonomi sudah banyak diteliti di beberapa negara. Sedikitnya ada dua kelompok memiliki perbedaan pendapat tentang pengaruh realisasi penerimaan pajak bagi pertumbuhan ekonomi. Pendapat pertama menyampaikan terdapat pengaruh yang positif dari realisasi penerimaan pajak bagi pertumbuhan ekonomi, diantaranya hasil dari penelitian Helen dan Theopilus (2013) di negara Nigeria, Takumah (2014) di negara Ghana dan Ardani dkk (2010) di Indonesia. Pendapat kedua menyampaikan bahwa adapengaruh yang negatif penerimaan pajak bagi pertumbuhan ekonomi, pendapat ini diungkapkan diantaranya hasildari penelitian yang dilakukan olehYi dan Suyono (2014) di Cina, oleh Gale, Krupkin dan Rueben (2015) di Amerika Serikat, dan Adu (2013) di Indonesia. Berdasarkan adanya perbedaan hasil penelitian diatas, studi ini ingin menganalisa tentang pengaruh realisasi penerimaan pajak bagi pertumbuhan ekonomi di negara Indonesia.

Unsur lain yang berpengaruh cukup penting untuk pertumbuhan ekonomi diantaranya adalah inflasi, pengangguran dan pendidikan. Beberapa penelitian sebelumnya menyatakan hasil yang berbeda dari pengaruh ketiganya bagi pertumbuhan perekonomian. Dampak inflasi terhadap pertumbuhan perekonomian adalah salah satu isu utama yang diteliti dalam makroekonomi. Beberapa pendapat muncul mengenai hubungan antara inflasi dan pertumbuhan ekonomi. Penelitian yang dilakukan Shahid (2014) di Nigeria, Umaru dkk (2013) di Nigeria dan Adu (2013) di
Indonesia menyatakan bahwa inflasi membawa pengaruh positif terhadap pertumbuhan ekonomi. Barro (2013) dalam penelitian di 100 negara dan Wibisono (2001) di Indonesia menyatakan bahwa inflasi memberikan pengaruh yang negatif bagi pertumbuhan perekonomian. Faria $\operatorname{dkk}(2001)$ pada penelitiannya di Brazil yang memakai Error Correction Model (ECM) memperoleh hasil yaitu dalam jangka pendek inflasi memberi pengaruh negatif sedangkan dalam jangka panjang inflasi memberi pengaruh positif terhadap pertumbuhan ekonomi.

Beberapa penelitian lain menyimpulkan bahwa tidak ada pengaruh signifikan antara inflasi dan pertumbuhan ekonomi. Penelitian yang menyimpulkan hasil demikian diantaranya adalah penelitian yang dilakukan oleh Asari dkk (2011) di Malaysia, yang dengan menggunakan ECM memperoleh hasil bahwa baik dalam jangka waktu pendek maupun jangka waktu panjang tidak memiliki pengaruh inflasi bagi pertumbuhan perekonomian.

Mosikari (2013) dalam penelitiannya tahun 1980-2011, member kesimpulan bahwa tidak terdapat pengaruh yang signifikan dari tingkat pengangguran bagi pertumbuhan perekonomian. Jonaidi (2012) menyimpulkan bahwa pengangguran memberikan pengaruh negatif terhadap pertumbuhan ekonomi (faktor ekonomi) sedangkan lama pendidikan sebagai faktor sosial memberikan pengaruh positif terhadap pertumbuhan ekonomi. Menurut Harrison dan Huntington (2000), analisis faktor sosial membantu memahami perilaku manusia terhadap konsumsi, tabungan, investasi, harapan dan perilaku ekonomi, yang akhirnya 
berdampak besar pada pertumbuhan ekonomi. Penelitan yang dilakukan Odit (2010) terhadap pengaruh pendidikan terhadap pertumbuhan ekonomi memberikan kesimpulan bahwa modal manusia memainkan peran penting dalam mempengaruhi pertumbuhan ekonomi. Lonni dkk (2012) dalam penelitiannya juga mendapatkan hasil bahwa tingkat pendidikan memberi pengaruh signifikan terhadap pertumbuhan ekonomi. Penelitian Khattak dan Khan (2012) di Pakistan dan Pengkas (2014) di Yunani menyatakan bahwa pendidikan dasar tidak memiliki pengaruh signifikan bagi pertumbuhan ekonomi.

Studi serta penelitian tentang pertumbuhan ekonomi dan faktor-faktor yang mempengaruhinya dianggap penting karena pertumbuhan ekonomi merupakan proses pertumbuhan output perkapita dalam jangka waktu panjang, sehingga menjadi indikator penting untuk menilai keberhasilan pada pembangunan ekonomi suatu negara, karenanya dalam konteks perekonomian suatu negara, pertumbuhan ekonomi menjadi salah satu target utama yang akan diperoleh dalam proses pembangunan.

Diantara satu instrumen yang dipakai pemerintah untuk memberi pengaruh pertumbuhan perekonomian adalah menerapkan kebijakan fiskal yakni kebijakan ekonomi makro untuk memberi efek tingkat aktivitas ekonomi dengan kendali belanja pengeluaran pemerintah dan pajak.Pajak merupakan faktor yang amat penting karena sebagai sumber penerimaan negara yang pokok dalam menopang pembiayaan bagi pembangunan, selain penerimaan nonpajak seperti migas serta non migas. Sumber APBN kira-kira 75\% dipenuhi dari pajak, jadi pajak sebagai penerimaan pemerintah yang paling signifikan untuk memenuhi APBN. Penerimaan pajak yang tinggi bisa memacu negara tertentu meningkatkan pengeluaran belanjabelanja pemerintah, sehingga bisa memacu perekonomian yang berujung bagi terciptanya peningkatan tingkat pertumbuhan ekonomi.

Soemitro, Rochmat menyampaikan bahwa pajak adalah iuran rakyat untuk kas negara yang didasarkan undang-undang (dapat dipaksakan) dengan tidak memperoleh timbal balik yang langsung bisa ditunjukkan dan digunakan membayar pengeluaran umum. Definisi pajak yang lain disampaikan oleh Brotodiharjo, R.Santoso (1993) bahwa pajak adalah kewajiban untuk memberikan sebagian dari kekayaan untuk negara disebabkan suatu keadaan, kejadian serta perbuatan yang memberikan kedudukan tertentu tetapi bukan merupakan sebagai hukuman, sesuai peraturan perundang-undangan yang telah ditetapkan pemerintah, dapat dipaksakan, tetapi tidak ada imbal balik dari negara secara langsung tetapi untuk memelihara kesejahteraan umum.

Mengoptimalkan penerimaan pajak amat diperlukan terkait dengan bertambahnya keperluan dana belanja rutin dan modal bagi pemerintah. Pajak untuk pemerintah bukan hanya sumber pendapatan, selain itu juga sebagai salah satu sarana kebijakan pemerintah untuk mengatur roda perekonomian. Tugas dan fungsi pendapatan pajak dilaksanakan oleh institusi Direktorat Jenderal Pajak yang berada di bawah Kementerian Keuangan Republik Indonesia untuk menghimpun pajak pemerintah pusat dan Pemerintah Daerah bagi Pajak Daerah, Retribusi, serta Pajak Bumi dan Bangunan (PBB) khusus sektor pedesaan 
dan perkotaan. Jenis-jenis dari pajak yang dikelola oleh Direktorat Jenderal Pajak meliputi (1) pajak pertambahan nilai (PPN) dan penjualan barang mewah (PPnBM), (2) pajak penghasilan (PPh), (3) pajak bumi dan bangunan (PBB) khususnya sektor pertambangan dan perkebunan dan (4) pajak Bea dan Meterai.

Inflasi dan pengangguran adalah indikator yang dapat dijadikan sebagai alat untuk menganalisa stabilitas perekonomian negara tertentu. Perubahan pada indikator ini akan memberi dampak kepada dinamika pertumbuhan ekonomi. Perekonomian yang berada dalam kondisi baik bagi suatu wilayah umumnya terwakili dengan tingkat inflasi yang cenderung rendah dan terkendali serta tingkat pengangguran yang rendah. Hubungan diantara pertumbuhan ekonomi terhadap tenaga kerja secara lebih rinci dapat tergambar melalui macam - macam indikator/ukuran, diantaranya dilihat melalui: elastisitas tenaga kerja, MPL (Marginal Productivity for Labor), dan ILOR (Incremental Labor Output Ratio). MPL merupakan tambahan produksi yang disebabkan penambahan satu tenaga kerja yang telah digunakan (Sukirno, 2013). ILOR adalah besarnya pertambahan tenaga kerja yang diperlukan untuk menaikkan satu unit output secara fisik maupun value, sedangkan elastisitas tenaga kerja adalah persentase penambahan tenaga kerja pada tiap satu persen pertumbuhan output.

Indikator yang penting lainnya pada pertumbuhan ekonomi yaitu tingkat pendidikan. Pendidikan adalah salah satu modal dasar manusia yang mesti dipenuhi guna mencapai pembangunan ekonomi yang berkesinambungan. Sektor pendidikan berperan utama sebagai pembentuk kemampuan sebuah negara dalam mengadopsi teknologi modern dan meningkatkan kapasitas produksi dan pembangunan yang berkelanjutan (Todaro, 2006).

Berdasarkan paparan diatas, penelitian ini difokuskan kepada analisis pengaruh penerimaan pajak bagi pertumbuhan ekonomi, disamping itu juga akan meneliti pengaruh inflasi, pengangguran dan pendidikan terhadap pertumbuhan perekonomian di Indonesia dalam periode penelitian selama 30 tahun yaitu tahun 1988 - 2017.

Skema hubungan diantara pertumbuhan dalam ekonomi dengan variabel-variabel yang dapat mempengaruhinya dapat digambarkan sebagai berikut:

Gambar 1. Skema Hubungan diantara Pertumbuhan Ekonomi terhadap Variabel-Variabel yang dapat Mempengaruhinya

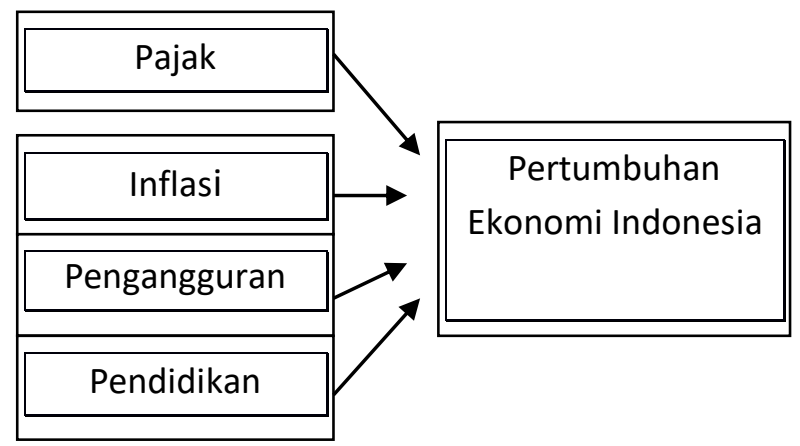

\section{METODEPENELITIAN}

\section{Sumber Data}

Data yang dipergunakan dalam penelitian ini jenisnya adalah data sekunder yang didapat dari Badan Pusat Statistik Indonesia serta beberapa sumber lain yang berhubungan dengan penelitian ini. Data yang dipergunakan secara rinci adalah sebagai berikut : 
1. PertumbuhanEkonomi: menggunakan data jumlah Produk Domestik Bruto Indonesia, dinyatakan padasatuan milyar rupiah.

2. Variabel Penerimaan Pajak: mempergunakan data realisasipenerimaan pajak di Indonesia, dinyatakan dalam satuan milyar rupiah.

3. Variabel Inflasi: menggunakan data tingkat inflasi di Indonesia, dinyatakan dalam persen $(\%)$.

4. Variabel Pengangguran: menggunakan jumlahpengangguran di Indonesia, dinyatakan dalam juta orang.

5. Variabel Tingkat Pendidikan: menggunakan data persentase jumlah penduduk umur 15 tahun keatas yang tamat Sekolah Menengah Atas dan Perguruan Tinggi di Indonesia, dinyatakan dalam satuan persen $(\%)$.

Data yang dipergunakan yaitu data sekunder selama periode tahun $1988 \mathrm{~s} / \mathrm{d}$ 2017.

Sumber data yang digunakan :

1. Statistik Indonesia tahun 1988 s/d 2017 BPS

2. PDRB Indonesia $1988 \mathrm{~s} / \mathrm{d}$ 2017;

3. Angkatan Kerja Indonesia tahun 1988 s/d 2017;
4. Berita Resmi Statistik Indonesia, beberapa edisi terbitan;

Metode Analisis Data

Metode analisis data yang dipergunakan penelitian ini yaitu model data runtun waktu (time series). Data runtun waktu merupakan data yang diperoleh dari beberapa tahun, dan data yang dipergunakan pada penelitian ini mulai dari tahun 1988 sampai dengan 2017. Penelitian ini adalah penelitian kuantitatif mempergunakan metodologi ekonometrika. Metodologi ekonometrika ini, alat analisis yang dipakai adalah analisis regresi, yakni alat analisis statistik tertentu yang didesain untuk mengukur arah serta besarnya pengaruh satu atau lebih variabel (variable independent), terhadap satu atau lebih variabel lain (variable dependen).

\section{Uji Error Correction Model (ECM)}

Error Correction Model (ECM) adalah model ekonometrika dinamis yang digunakan pada data runtun waktu (time series). Estimasi pengaruh empat variabel independen dalam model teoritis di atas dilakukan dengan menggunakan Model Koreksi Kesalahan atau Error Correction Model (ECM), yang diformulasikan sebagai model ekonometrik sbb:

$$
\begin{aligned}
\Delta \log \left(P D B_{t}\right)= & \gamma_{0}+\gamma_{1} \Delta I N F_{t}+\gamma_{2} \Delta \log \left(U E M P_{t}\right)+\gamma_{3} \Delta \log \left(T A X_{t}\right)+\gamma_{4} \Delta E D U C_{t} \\
& +\gamma_{5} I N F_{t-1}+\gamma_{6} \log \left(U E M P_{t-1}\right)+\gamma_{7} \log \left(T A X_{t-1}\right)+\gamma_{8} E D U C_{t-1} \\
& +\gamma_{9} E C T_{t}+v_{t}
\end{aligned}
$$

dimana :

PDB = Produk Domestik Bruto

INF $=$ Inflasi

UEMP = Jumlah Pengangguran

TAX = Penerimaan Pajak Pemerintah

EDUC $=$ Tingkat Pendidikan

$\beta_{0}=$ Konstanta

$$
\beta_{1} \cdots \beta_{4}=\begin{gathered}
\text { Pengaruh jangka panjang } \\
\text { variabel independen }
\end{gathered}
$$

$u_{t}=$ Error Term

Log $=$ Operator logaritma natural (basis

e) 
$E C T=I N F t-1+\log (U E M P) t-$

$1+\log (\mathrm{TAX} t-1)+I N F t-1-\log (P D B) t-1$

$\gamma 0=\alpha 5 \beta 0$

$\gamma 1=\alpha 1 ; \gamma 2=\alpha 2 ; \gamma 3=\alpha 3 ; \gamma 4=\alpha 4$

$\gamma 5=-\alpha 5(1-\beta 1) ; \gamma 6=-\alpha 5(1-\beta 2) ; \gamma 7=-$

$\alpha 4(1-\beta 3) ; \gamma 8=-\alpha 5(1-\beta 4)$

$\gamma 9=\alpha 5$ (parameter penyesuaian)

$v_{t}=$ Error Term

Estimasi model koreksi kesalahan yang menggunakan metode estimasi OLS, menunjukkan hasil seperti tampak pada Tabel 1. Koefisien ECT tampak memiliki nilai positif dan besarnya antara 0-1. Nilai koefisien ini, secara statistik signifikan.Sehingga masih dapat diterima kesimpulan bahwa model koreksi kesalahan merupakan model yang tepat atau sesuai dengan teori dan bisa dipergunakan untuk mengestimasi berbagai faktor yang diuji dalam model Uji Diagnosis

(1) Otokorelasi

$\mathrm{x}^{2}(3)=0.7641 ;$ Prob. $=0,8580$

(2) Linieritas

$\mathrm{F}(2,17)=0.5436 ;$ Prob. $=0.5905$

(3) Normalitas

$\mathrm{x}^{2}(2)=0.6436 ;$ Prob. $=0,7248$

(4) Heteroskedastisitas

$\mathrm{x}^{2}(9)=8.0293 ;$ Prob. $=0,5312$

Jangka Pendek :

Tabel 1. Hasil Estimasi Model Koreksi Kesalahan

$$
\begin{aligned}
& \Delta \log \left(P D B_{t}\right)=1.3915+0.0029 \Delta I N F_{t}-0.0360 \Delta \log \left(U E M P_{t}\right) \\
&+0.2242 \Delta \log \left(T A X_{t}\right)-0.0019 \Delta E D U C_{t}-0.2821 I N F_{t-1}-0.2276 \log \left(U E M P_{t-1}\right) \\
&-0.1609 \log \left(T A X_{t-1}\right)-0.2604 E D U C_{t-1}+0.2907 E C T_{t}+v_{t}
\end{aligned}
$$

Jangka Panjang :

$$
\begin{aligned}
& \Delta \log \left(P D B_{t}\right)=4.7868+0.0296 \Delta I N F_{t}+0.2169 \Delta \log \left(U E M P_{t}\right) \\
& +0.4464 \log \left(\text { TAX }_{t}\right)+0.1042 E D U C_{t}
\end{aligned}
$$

$$
\mathrm{R}^{2}=0.8187 ; \quad \text { DW-Stat }=1.9223 ; \quad \text { F-Stat }=9.5332
$$

\section{Uji Asumsi CLRM}

Uji asumsi CLR Mini dilakukan karena di dalam model regresi perlu perhatian adanya unsur penyimpanganpenyimpangan atas asumsi klasik, disebabkan pada hakekatnya jika asumsi klasik tidak dipenuhi maka variabelvariabel yang menjelaskan akan menjadi tidak efisien.

\section{a. Uji Normalitas}

Pengujian untuk mengetahui apakah distribusi data normal atau tidak dilakukan dengan uji Jarque Bera atau JB test, jika nilai $\mathrm{J}-\mathrm{B}$ hitung > J-B tabel, atau bisa dilihat dari nilai probability Obs*R-Squared lebih besar dari taraf nyata 5 persen berarti data berdistribusi normal.

Hasil Uji J-B dapat dilihat padaGambar 2. Gambar diatas menunjukan bahwa JBhitung sebesar 0,643. Nilai JB-hitung kemudian dibandingkan dengan $\chi^{2}$ tabel yang probabilitasnya sebesar $5 \% \mathrm{df}=29$ 
- $4=25$, diperoleh nilai $\chi 2$ tabel sebesar 37,652. Karena nilai JB-hitung $(0,643)<$ $\chi 2$ tabel $(37,652)$ artinya semua data berdistribusi secara normal dan tidak adanya penyimpangan, sehingga data yang dikumpulkan dapat diproses dengan metode-metode selanjutnya.

Gambar 2. Hasil Uji Normalitas Residual Jarque Bera

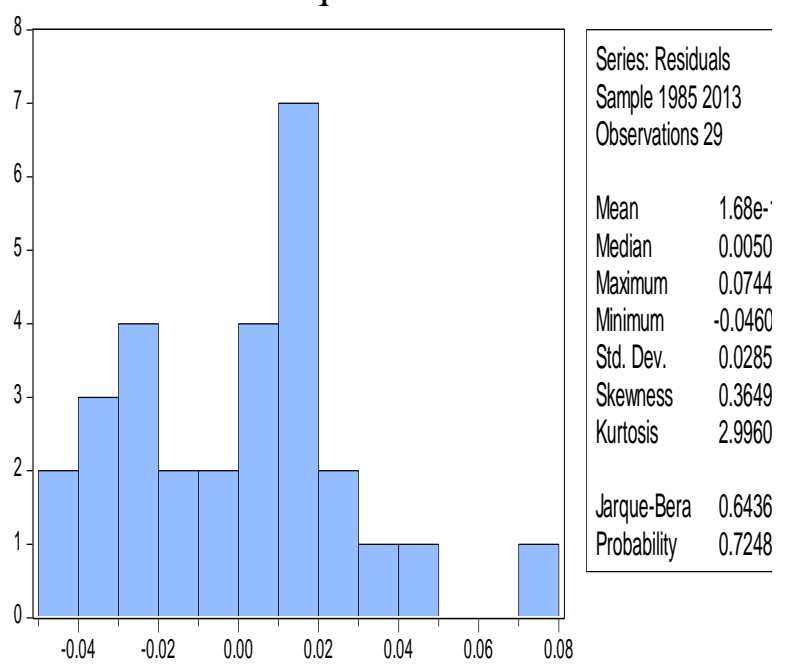

\section{b. Uji Autokorelasi}

Dalam penelitian ini digunakan uji Breusch-Godfrey untuk mengetahui ada tidaknya autokorelasi.

Tabel 2. Hasil Uji Breusch-Godfrey (BG)

\begin{tabular}{|l|l|l|l|}
\hline & 0.144331 & & 0.9318 \\
\hline & 0.764121 & & 0.8580 \\
\hline
\end{tabular}

Dari hasil perhitungan uji autokorelasi tabel diatas didapat nilai Obs*R-squared atau $\chi 2$ hitung sebesar 0,7641 dan $\chi^{2}$ tabel sebesar 37,652. Berdasarkan hasil tersebut maka $\chi^{2}$ hitung $(0,7641)<\chi^{2}$ tabel $(37,652)$, sehingga dapat disimpulkan pada model estimasi tidak ditemukan autokorelasi. Dapat juga dilihat dari probabilitas Chi Square yang nilainya 0,8580 lebih besar dari 0.05 sehingga dapat ditarik kesimpulan bahwa tidak terjadi autokorelasi.

\section{c. Uji Heteroskedastisitas}

Dalam penelitian ini, untuk mendetekasi fenomena heteroskedastisitas digunakan Uji White. Berdasarkan hasil perhitungan melaui uji heteroskedastisitas metode White menghasilkan nilai $O b s^{*} R$-squared atau $\chi^{2}$ hitung sebesar 8,029. Jika nilai $\chi^{2}$ hitung $<\chi 2$ tabel, maka hipotesis yang menyatakan bahwa terjadi heteroskedastisitas adalah ditolak. Nilai $\chi 2$ hitung sebesar 8,029 , sedangkan nilai $\chi^{2}$ tabel dengan $\mathrm{df}=29-4=15$ sebesar 37,652, maka dapat disimpulkan bahwa $\chi^{2}$ hitung $(8,029)<\chi^{2}$ tabel $(37,652)$ sehingga dapat disimpulkan bahwa model regresi persamaan tersebut tidak terdapat gejala heteroskedastisitas. Kesimpulan juga dapat dilihat dari nilai probability Obs* $R$-squared 0,5312>0,05, hal ini menunjukkan model ini tidak ada masalah heteroskedastisitas.

\section{d. Uji Spesifikasi Model (Ramsey's Reset Test)}

Uji ini dilakukan untuk menguji ada tidaknya kesalahan spesifikasi dalam regresi. Uji linearitas dalam suatu model dapat dideteksi dengan menggunakn uji Ramsey Reset Test.

Dapat terlihat dari probability Fhitung lebih besar dari probability $\alpha$ $(0.5905>0,05)$. Hal ini mengindikasikan bahwa model yang dipakai berbentuk linear.

Seluruh uji diagnosis, yang meliputi uji normalitas residual, uji otokorelasi, uji heteroskedastisitas (homoskedastisitas), dan uji linieritas atau ketepatan spesifikasi model, menunjukkan tidak adanya penyimpangan asumsi klasik. Hal ini dapat ditunjukkan dari keseluruhan 
probabilitas statistik uji diagnosis, yang memiliki nilai lebih besar dari 0,05 .

\section{PEMBAHASAN}

\section{Penerimaan Pajak}

Penerimaan Pajak dalam jangka pendek dan jangka panjang memberikan pengaruh positif terhadap PDB Indonesia. Hal ini menunjukkan bahwa semakin meningkat realisasi penerimaan pajak, maka pertumbuhan perekonomian di Indonesia akan meningkat juga. Dalam jangka pendek, apabila terjadi kenaikan pendapatan pajak sebesar 1 persen, maka pendapatan nasional akan naik sebesar 0,2242 persen, sedangkan dalam jangka panjang, apabila terjadi kenaikan pendapatan pajak sebesar 1 persen, maka pendapatan nasional akan bertambah naik sebesar 0,4464 persen. Hasil penelitian tersebut sesuai dengan hipotesis pada penelitian ini.Beberapa penelitian sebelumya juga menunjukkan hasil yang sama. Ardani dkk.(2009), juga menyimpulkan bahwa penerimaan pajak dan belanja pembangunan memberikan pengaruh positif dan signifikan. Demikian juga Alkadri (2006) dalam penelitiannya juga menyimpulkan bahwa variabel yang memiliki pengaruh positif terhadappertumbuhan ekonomi adalah PMA, PMDN, bantuan luar negeri, penerimaan pajak, pertumbuhan angkatan kerja dan pengeluaran pemerintah. Berarti dalam pengelompokan yang disampaikan pada latar belakang penelitian diatas, Indonesia masuk dalam kelompok pertama yaitu masuk dalam kelompok negara yang tingkat penerimaan pajaknya memberi pengaruh positif terhadap pertumbuhan ekonomi.

\section{Inflasi}

Koefisien inflasi dalam jangka waktu pendek dan jangka waktu panjang terlihat memiliki pengaruh positif dan signifikan kepada penda-patan nasional bruto perekonomian Indonesia, walaupun dengan pengaruh yang sangat kecil. Nilai elastisitas inflasi dalam jangka pendek sebesar 0,0029, berarti apabila terjadi inflasi sebesar satu persen maka PDB akan mengalami kenaikan sebesar 0,0029 persen. Dalam jangka panjang apabila terjadi inflasi sebesar satu persen maka PDB akan bergerak kurang lebih 0,0296 persen. Dilihat dari nilai koefisien regresi yang lebih kecil dari satu, berarti inflasi bersifat inelastis terhadap pertumbuhan ekonomi. Hasil tersebut tidak sesuai dengan hipotesis pada penelitian ini, tapi pada prinsipnya tidak semua efek inflasi berakibat negatif bagi perekonomian, terutama apabila terjadi inflasi ringan yaitu inflasi yang di bawah sepuluh persen. Inflasi ringan justru bisa mendorong pertumbuhan ekonomi. Hal ini disebabkan inflasi akan dapat memberi semangat pada pengusaha, untuk lebih menambah produksinya. Pengusaha bertambah semangat memperluas produksinya, karena dengan kenaikan harga diharapkan para pengusaha mendapat lebih banyak keuntungan. Disamping itu, meningkatnya produksi memberi akibat positif yang lain, yaitu tersedianya lapangan kerja baru. Inflasi akan berdampak negatif apabila nilainya melebihi sepuluh persen.

Inflasi memiliki dampak yang positif dan juga dampak negatif.

1. Dampak positif:

a. Peredaran barang lebih cepat.

b. Produksi barang-barang meningkat, disebabkan karena keuntungan pengusaha jadi bertambah.

c. Kesempatan lapangan kerja bertambah, karena terjadi penambahan investasi. 
d. Pendapatan nominal semakin tambah, tetapi riil kurang, karena kenaikan pendapatan kecil.

2. Dampak negatif:

a. Harga jasa dan barang-barang naik.

b. Nilai dan kepercayaan terhadap nilai tukar uang akan semakin turun atau berkurang.

c. Memunculkan usaha spekulasi.

d. Proyek pembangunan banyakterlantar atau macet.

e. Kesadaran masyarakat untuk menabung semakin kurang.

Studi keterkaitan inflasi dan pertumbuhan ekonomi banyak menimbullkan temuan bahwa antar keduanya dapat memiliki hubungan negatif atau dapat pula tidak ada korelasi yang signifikan. Karena itu keputusan masih dianggap tidak pasti, sehingga penelitian terhadap hal tersebut masih banyak dilakukan.

Pertumbuhan ekonomi dunia yang tidak stabil ikut menekan inflasi untuk jangka pendek. Tingkat kenaikan harga yang tidak terkendali akan memperburuk tingkat inflasi dan bias saja mampu melumpuhkan perekonomian negara itu. Dilihat melalui sisi makro ekonomi, tingkat inflasi yang tinggi akan mengurangi nilai saing negara. Tingkat inflasi rendah atau sederhana tidak memberi pengaruh yang buruk pada pertumbuhan ekonomi, namun inflasi yang terlalu rendah dan terlalu tinggi bisa membuat lemah pertumbuhan ekonomi. Bukti statistik di negara - negara berkembang Afrika dan Amerika Latin mengindikasikan bahwa pertumbuhan PDB berdampak negatif terhadap inflasi (Ericsson dkk, 2001). Bukti lain di Fiji, pertumbuhan ekonomi bisa mengurangi laju inflasi walau dalam derajad yang tidak terlalu signifikan (Gokal\&Hanif,
2004). Pakar ekonomi bersepakat mengatakan bahwa tingkat inflasi yang tinggi berawal dari tingkat pertumbuhan penawaran uang yang tinggi. Namun, menurut Mubarik (2005), inflasi pada tahap kurang dari 9\% dapat membantu meningkatkan pertumbuhan ekonomi. Penelitian Fischer (1993), pada tahun 1985 mendapatkan hasil bahwa hubungan pertumbuhan ekonomi dengan inflasi adalah negatif pada jangka waktu panjang dan hubungan positif pada jangka waktu pendek. Kesimpulannya, tidak ada bukti yang pasti terhadap hubungan antara inflasi dengan pertumbuhan ekonomi pada jangka waktu pendek maupun dalam jangka waktu panjang (Antoni, 2010).

\section{Pengangguran}

Pengangguran dalam jangka yang pendek ternyata juga berpengaruh negatif tetapi tidak signifikan kepada pendapatan nasional, sedangkan dalam jangka panjang justru memberikan pengaruh positif dan signifikan terhadap pendapatan nasional bruto. Dalam jangka panjang, koefisien regresi pengangguran sebesar 0,2169 persen, artinya apabila pengangguran naik 1 persen maka PDB akan naik sebesar 0,2169 persen. Penyebab dari hal ini adalah karena pertumbuhan ekonomi di Indonesia memiliki orientasi padat modal bukannya padat karya. Dari distribusi persentase PDB menurut sektor lapangan usaha, ditunjukkan bahwa sektor industri dominan menyumbang sumber pendapatan, namun sektor tersebut menyerap tenaga kerja tidak lebih darihanya 13 persen. Hal ini sesuai penelitian yang dilakukan Syahwier (2005) dan juga yang dilakukan oleh Wardhana (2006). Keduanya memiliki hasil yang sama mengenai pengaruh GDP dan tingkat pengangguran dimana kenaikan GDP tidak memiliki pengaruh 
pada penyerapan tenaga kerja. Hal ini karena kontribusi yang terbesar pada pertumbuhan ekonomi adalah sektor industri manufaktur dimana pada sektor tersebut pertumbuhan yang terjadi pada industri-industri padat modal bukan padat karya.

Berdasarkan beberapa penelitian terdahulu, hubungan antara pengangguran dan pertumbuhan ekonomi menunjukkan hasil yang memang berbeda, hubungan Pertumbuhan Ekonomi dan besarnya pengangguran ada yang bersifat positif dan ada pula negatif. Pertumbuhan ekonomi berdasarkan GDP bersifat positif dikarenakan pertumbuhan ekonomi tidak diiringi oleh peningkatan kapasitas produksi, sehingga jumlah pengangguran tetap bertambah seiring dengan pertumbuhan ekonomi. Peningkatan ekonomi ini berorientasi pada padat modal,yang mana kegiatan produksi untuk mempercepat output dan menghasilkan pendapatan yang bertambah lebih diutamakan daripada pertumbuhan ekonomi yang berorientasi pada padat karya. Pertumbuhan ekonomi yang memiliki orientasi pada padat modal Cuma akan mengutamakan pendapatan nasional yang cukup besar tanpa memberikan kesempatan lapangan kerja yang lebih besar kepada pekerja, sehingga pertumbuhan ekonomi yang berorientasi padat modal ini tidak memiliki pengaruh terhadap penyerapan tenaga kerja, hal itu memberikan indikasi pertumbuhan ekonomi yang meningkat akan diiringi dengan besarnya pengangguran yang bertambah (Ghofari, 2010).

\section{Pendidikan}

Tingkat pendidikan dalam jangka pendek tidak memberikan pengaruh signifikan terhadap pertumbuhan ekonomi, tetapi dalam jangka panjang kenaikan tingkat pendidikan akan memberikan pengaruh yang positif dan signifikan terhadap pendapatan nasional Indonesia, dimana apabila tingkat pendidikan meningkat 1 persen maka PDB akan naik sekitar 0,1042 persen. Hasil seperti ini juga sesuai dengan penelitian sebelumnya yang dilakukan oleh Prasasti (2006) dalam penelitiannya memberikan hasil bahwa variabel penduduk tamat SMA positif dan signifikan dalam memberi pengaruh terhadap penerimaan PDRB suatu wilayah. Demikian juga penelitian oleh Pancawati, 2000 dengan judul Pengaruh rasio capital tenaga kerja, tingkat pendidikan, stok capital dan pertumbuhan penduduk terhadap GDP Indonesia capital berpengaruh positif terhadap pertumbuhan output. Demikian juga penelitian oleh Suryanto (2009) menyimpulkan bahwa tenaga kerja, pengeluaran pemerintah dan tingkat pendidikan memberikan pengaruh positif dan signifikan bagi pertumbuhan ekonomi.

\section{SIMPULAN}

Berdasarkan hasil dari penelitian dan pembahasanmengenai pengaruh dariinflasi, pengangguran, penerimaan dari pajak dan tingkat pendidikan bagi pertumbuhan ekonomi di Indonesia tahun 1984-2013 dengan menggunakan pendekatan Error Correction Model (ECM) dan asumsi klasik maka dapat diambil kesimpulan bahwa Penerimaan Pajak dalam jangka panjang maupun jangka pendek memberikan dampak yang cukup besar terhadap output nasional. Potensi penerimaan pajak di Indonesia masih bisa digali, disamping jumlah penduduk yang besar dapat juga dilihat dari pelaku-pelaku bisnis yang 
masih belum sebagai wajib pajak, sehingga perlu upaya yang lebih kuat dari pemerintah untuk meningkatkan penerimaan pajak diantaranya dengan semakin memperbaiki sistem perpajakan nasional dan 'membersihkan' mental pegawai pajak supaya anti korupsi untuk meningkatkan kepercayaan masyarakat wajib pajak.

Selain itu, Pemerintah harus melakukan berbagai upaya untuk mengontrol dan mengendalikan angka inflasi. Inflasi pada umumnya berpengaruh buruk terhadap pertumbuhan ekonomi, tetapi ketika inflasi dapat dikontrol pada angka dibawah $10 \%$ justru bisa memberikan pengaruh yang positif dalam meningkatkan pertumbuhan ekonomi. Berdasarkan hasil hubungan antara pertumbuhan ekonomi dan pengangguran pada penelitian diatas, maka untuk menekan jumlah pengangguran seharusnya pertumbuhan ekonomi lebih berorientasi pada padat karya. Sektor-sektor dominan semisal sektor industri diharapkan dapat meningkatkan kapasitas produksi supaya tenaga kerja dapat banyak terserap sehingga jumlah pengangguran dapat dikurangi dan pertumbuhan ekonomi juga tetap bisa ditingkatkan.Amartya Sen, seorang ahli dalam pembangunan mengatakan inti dari kemajuan bangsa adalah kemajuan sumber daya manusianya, sejauh apa manusia di negara tersebut dapat bahagia, berdaya, bebas, berkreasi, berinovasi, mengaktualisasikan dirinya, mencerdaskan dirinya, merasa aman, menjadi sehat (fisik dan mental) dan seterusnya. Angka-angka untuk membangun keunggulan sebuah bangsa yang sesungguhnya bukan sekedar akumulasi materi yang belum pasti kokoh dalam jangka panjang, sehingga pemerintah harus memberikan perhatian lebih pada sektor pendidikan sebagai salah satu modal penting dalam peningkatan pertumbuhan ekonomi, dengan membuat kebijakan-kebijakan yang bisa meningkatkan mutu dan kualitas pendidikan di Indonesia.

\section{DAFTAR PUSTAKA}

Adu, Isay S.H., 2013. "Dampak Kebijakan Fiskal, Kebijakan Moneter, Kestabilan Perekonomian Nasional serta Dunia terhadap Pertumbuhan Ekonomi Indonesia". Jurnal Makroekonomi, Sekolah Tinggi Ilmu Statistik, 2013.

Antoni. 2010. "Kointegrasi Antara Inflasi dan Pertumbuhan Ekonomi di Indonesia”. Jurnal Ekonomi, Bisnis dan Koperasi Vol.12, No.2, Oktober 2010.

Badan Pusat Statistik, Berbagai Tahun Terbitan. Berita Resmi Statistik. Badan Pusat Statistik.

Badan Pusat Statistik, Berbagai Tahun Terbitan. Statistik Indonesia. Badan Pusat Statistik.

Boediono. 2001. Ekonomi Makro. BPFE. Yogyakarta

Dharendra Wardhana. 2006. "Pengangguran Struktural di Indonesia: Keterangan dari Analisis SVAR Dalam Kerangka Hysteresis". Jurnal Ekonomi dan Bisnis Indonesia vol.3, 2006. Universitas Gadjah Mada.

Dombusch, Rudiger dan Stanley Fischer. 1994. Ekonomi Makro Edisi Kelima. PT Rineka Cipta. Jakarta. 
Jonaidi, Arius. 2012. "Analisis Pertumbuhan Ekonomi dan Kemiskinan di Indonesia". Jurnal Kajian Ekonomi Vol. 1, No.1, hal 140-164 April 2012

Khattak, Naeem Ur Rehman dan Jangraiz Khan. 2012. "The Contribution of Education to Economic Growth". International Journal of Business and Social Science, Vol.3 No. 4 Februari 2012

Mosikari, Teboho Jeremiah. 2013. The Effect of Unemployment Rate on Gross Domestic Product". Economics Department, North West University (NWU), 2013.

Mubarik Y.A. 2005 "Inflation and Growth: An Estimate of the Threshold Level of inflation in Pakistan". SBP Research Buletin.

Otu, Helen Buki dan Theophilus Oyime Adejumo. 2013. "The Effects of Tax Revenue on Growth in Nigeria". International Journal of Humnities and Social Science Invention, Vol.2 issue $6 \mathrm{hlm}$ 16-26 Juni 2013.

Odit, Mohun P.. 2010. "The Impact of Education On Economic Growth". International Business\&Economics Research Journal, Vol. 9 hal 8-24, Agustus 2010.

Pancawati, Neni, 2000. "Pengaruh Rasio Kapital Tenaga Kerja, Tingkat Pendidikan, Stok Kapital dan Pertumbuhan Penduduk terhadap Tingkat Pertumbuhan GDP Indonesia". Jurnal Ekonomi dan Bisnis Indonesia, Vol.15, No.02. Universitas Gajah Mada. Yogyakarta.

Pegkas, Panagiotis. 2014. "The Link between Educational Levels anf Economic Growth". International Journal of Applied Economics hal 38-54, September 2014.

Srthongrung, Arwiphawee dan Isaac Sanchez Juarez, 2015. "FiscalPolicies and Subnational Economic Growth in Mexico". International Journal of Economics and Financial Issues Vol.5, No.1, 2015.

Sukirno, Sadono. 2013. Makroekonomi Teori Pengantar, Edisi Ketiga, Rajawali Press, 2013.

Takumah, Wisdom, 2014. "The Effect of Tax Revenue on Growth in Nigeria". MPRA Paper No. 58532, September 2014.

Todaro, P.M. dan Smith, S.C. 2011. Pembangunan Ekonomi. Edisi 11 Jilid 1. Erlangga, Jakarta.

Umaru, Aminu: Manu Donga dan Saliha Musa, 2013. "An Empirical Investigation in to the Effect of Unemployment and Inflation on Economic Growth in Nigeria". Interdisciplynary Journal of Research in Business. Vol. 2, 2013.

Utomo, Yuni Prihadi. 2015. Eksplorasi Data\&Analisis Regresi. Muhammadiyah University Press. Surakarta.

Wibisono, Yusuf.2005. "Sumber-Sumber Pertumbuhan Ekonomi Regional: Studi Empiris Antar Propinsi di Indonesia, 1984-2000". Journal Ekonomi dan Bisnis Indonesia Vol. 2, Universitas Gajah Mada, 2005.

Yi, Feng dan Eko Suyono. 2014. "Relationship between Tax Revenue and Economic Growth of Hebei Province Based on The Tax Multiplier Effect". Global Economy and Finance Journal, Vol.7, No. 2 Hal 1-18, September 2014. 